\title{
Clinical responses to EGFR-tyrosine kinase inhibitor retreatment in non-small cell lung cancer patients who benefited from prior effective gefitinib therapy: a retrospective analysis
}

Satoshi Watanabe ${ }^{1 *}$, Junta Tanaka², Takeshi Ota', Rie Kondo ${ }^{1}$, Hiroshi Tanaka², Hiroshi Kagamu', Kosuke Ichikawa', Jun Koshio', Junko Baba', Takao Miyabayashi', Ichiei Narita', Hirohisa Yoshizawa ${ }^{2}$

\begin{abstract}
Background: Gefitinib was the first epidermal growth factor receptor-tyrosine kinase inhibitor (EGFR-TKI) approved for the treatment of advanced non-small cell lung cancer (NSCLC). Few treatment options are available for NSCLC patients who have responded to gefitinib treatment and demonstrated tumor progression. The present study was conducted to evaluate the efficacy and toxicity of the $2^{\text {nd }}$ EGFR-TKI administration.

Methods: We retrospectively analyzed 11 patients who had obtained a partial response (PR) or stable disease (SD) with gefitinib treatment and were re-treated with EGFR-TKI after failure of the initial gefitinib treatment.

Results: Three patients (27\%) were treated with gefitinib as the $2^{\text {nd }}$ EGFR-TKI, and 8 patients (73\%) received erlotinib. Only one patient (9\%) showed PR, 7 (64\%) achieved SD, and 3 (27\%) had progressive disease. The disease control rate was $73 \%(95 \% \mathrm{Cl}, 43 \%-91 \%)$ and the median progression-free survival was 3.4 months $(95 \% \mathrm{Cl}$, 2 - 5.2). The median overall survival from the beginning of the $2^{\text {nd }}$ EGFR-TKI and from diagnosis were 7.3 months $(95 \% \mathrm{Cl}, 2.7-13)$ and 36.7 months $(95 \% \mathrm{Cl}, 23.6$ - 43.9), respectively. No statistical differences in PFS or OS were observed between gefitinib and erlotinib as the $2^{\text {nd }}$ EGFR-TKI (PFS, $P=0.23$ and $O S, P=0.052$ ). The toxicities associated with the $2^{\text {nd }}$ EGFR-TKI were generally acceptable and comparable to those observed for the initial gefitinib therapy.
\end{abstract}

Conclusions: Our results indicate that a $2^{\text {nd }}$ EGFR-TKI treatment can be an effective treatment option for gefitinib responders.

\section{Background}

Gefitinib was the first epidermal growth factor receptor tyrosine kinase inhibitor (EGFR-TKI) to become available for the treatment of non-small cell lung cancer (NSCLC). Several studies have demonstrated that gefitinib is effective for the second-line treatment of NSCLC [1-3]. Although the phase III ISEL trial failed to prove the superiority of gefitinib treatment compared to placebo in previously treated patients, a subgroup analysis demonstrated improved survival in particular populations

\footnotetext{
* Correspondence: satoshimd@yahoo.co.jp

'Department of Medicine (II), Niigata University Medical and Dental Hospital, Niigata City, Niigata, Japan

Full list of author information is available at the end of the article
}

(Asians and non-smokers) [4]. Further analyses in other studies have also revealed that clinical factors (Asians, females, non-smokers, and adenocarcinoma histology) are associated with the response to gefitinib treatment [5]. EGFR mutations, such as the deletion of exon 19 and the single L858R mutation in exon 21 , have also been reported to be correlated with a longer survival and were found more frequently in Asian patients [6-8]. Recently, a superior progression-free survival (PFS) with gefitinib compared with the combination of carboplatin and paclitaxel in untreated NSCLC patients with predictors of gefitinib sensitivity was proven in two large phase III studies $[9,10]$. Gefitinib is now recommended for advanced

\section{Ciomed Central}


or metastatic NSCLC patients under such circumstances as a first or a second-line treatment.

Despite the high disease control rate (DCR), gefitinib treatment is not curative and eventually there is disease recurrence, even in patients with predictors of sensitivity. For the many NSCLC patients who previously responded to gefitinib but later showed tumor progression, very few treatment options are available.

Some investigators have conducted studies to evaluate the efficacy of EGFR-TKI re-administration [11-14]. In most of those studies, both gefitinib responders and non-responders were retreated with gefitinib or erlotinib, and gefitinib responders tended to benefit from the $2^{\text {nd }}$ EGFR-TKI.

Here, we retrospectively analyzed the efficacy of the $2^{\text {nd }}$ EGFR-TKI administration after failure of the initial gefitinib treatment in NSCLC patients who had previously achieved disease control with gefitinib. The risks of the $2^{\text {nd }}$ administration of EGFR-TKI, especially the association with adverse events in the initial gefitinib treatment, were also evaluated.

\section{Methods}

\section{Patients}

We conducted a retrospective search of the medical records at Niigata University Medical and Dental Hospital, from June 2005 through October 2009, and we identified 11 NSCLC patients who had obtained a partial response (PR) or stable disease (SD) with gefitinib treatment and undergone EGFR-TKI retreatment sometime after the failure of the initial gefitinib treatment. All patients were treated initially with oral gefitinib at a dose of $250 \mathrm{mg} /$ day, which was continued until either a radiographic tumor or overt clinical progression was observed. The same dose of gefitinib, or erlotinib at a dose of $150 \mathrm{mg} /$ day, was used for EGFR-TKI retreatment and continued until tumor progression was detected.

\section{Assessment of the response and adverse events}

The tumor response was evaluated by radiologic examinations according to the Response Evaluation Criteria in Solid Tumors (RECIST) [15]. Disease control was defined as complete response (CR), PR or SD. PFS and overall survival (OS) were defined as the period from the start of the treatment to the date when disease progression and death, respectively, were observed.

Adverse events were assessed according to Common Terminology Criteria for Adverse Events of the National Cancer Institute (version 3.0) [16].

\section{Statistical analysis}

PFS and OS estimates were obtained using the KaplanMeier method.
Table 1 Patient Characteristics 1

\begin{tabular}{|c|c|c|}
\hline Characteristics & No. of Patients & $\%$ \\
\hline Total enrolled & 11 & \\
\hline \multicolumn{3}{|l|}{ Gender } \\
\hline Female & 8 & 73 \\
\hline Male & 3 & 27 \\
\hline \multicolumn{3}{|l|}{ Age (y) } \\
\hline Median & 55 & \\
\hline Range & $46-70$ & \\
\hline \multicolumn{3}{|c|}{ ECOG performance status } \\
\hline 1 & 6 & 55 \\
\hline 2 & 0 & 0 \\
\hline 3 & 3 & 27 \\
\hline 4 & 2 & 18 \\
\hline \multicolumn{3}{|l|}{ Histology } \\
\hline Adenocarcinoma & 10 & 91 \\
\hline Squamous & 1 & 9 \\
\hline \multicolumn{3}{|l|}{ Smoking history } \\
\hline Current & 3 & 27 \\
\hline Ex-smoker & 1 & 9 \\
\hline Never & 7 & 64 \\
\hline \multicolumn{3}{|l|}{ EGFR mutation } \\
\hline Exon 19 deletion & 2 & 18 \\
\hline L858R & 1 & \\
\hline Not available & 8 & 73 \\
\hline
\end{tabular}

EGFR, epidermal growth factor receptor.

\section{Results}

Patient characteristics

Of the 11 identified patients who benefited from gefitinib and were retreated with EGFR-TKI, 3 patients (27\%) received gefitinib and 8 patients (73\%) received erlotinib as the $2^{\text {nd }}$ round of EGFR-TKI. As shown in Table 1 the ages of patients ranged from 46 to 70 years (median, 55 years), and there were 8 females (73\%), 7 non-smokers (64\%), and 10 adenocarcinoma patients (91\%). Three patients (27\%) exhibited EGFR gene mutations, but the mutation statuses of the other 8 patients (73\%) were not determined. All patients had received platinum-based chemotherapy before the initial gefitinib treatment. The patient characteristics, including treatment backgrounds and responses, are summarized in Table 2.

\section{Response to the initial gefitinib treatment}

During the $1^{\text {st }}$ EGFR-TKI treatment with gefitinib, 8 patients achieved PR as the best response (73\%, Table 3 ), and 3 patients (27\%) were SD. The median PFS was 9.8 months, with a $95 \%$ CI of 6.6 to 16.7 months.

\section{Response to the $2^{\text {nd }}$ EGFR-TKI}

Three patients (27\%) received the $2^{\text {nd }}$ EGFR-TKI immediately after gefitinib failure, and 8 (73\%) underwent 1 cytotoxic regimen between the initial gefitinib and the 
Table 2 Patient Characteristics 2

\begin{tabular}{|c|c|c|c|c|c|c|c|c|c|c|c|c|c|}
\hline Case & $\begin{array}{l}\text { Age } \\
\text { (y) }\end{array}$ & Gender & Smoking & Histology & $\begin{array}{l}\text { EGFR } \\
\text { mutation }\end{array}$ & $\begin{array}{l}\text { PFS to } \\
1^{\text {st }} \text { TKI }\end{array}$ & $\begin{array}{c}\text { TKI } \\
\text { sequence }\end{array}$ & $\begin{array}{l}\text { Interval from } \\
1^{\text {st }} \text { and } 2^{\text {nd }}\end{array}$ & $\begin{array}{l}\text { Chemo. } \\
\text { after } 1^{\text {st }}\end{array}$ & PS & Response & $\begin{array}{l}\text { PFS to } \\
2^{\text {nd }} \text { TKI }\end{array}$ & $\begin{array}{l}\text { OS from } \\
2^{\text {nd }} \text { TKI }\end{array}$ \\
\hline 1 & 50 & $\mathrm{~F}$ & Current & $\mathrm{Ad}$ & NA & 9.8 & $\mathrm{G} \rightarrow \mathrm{E}$ & 7.9 & $\begin{array}{l}\text { CBDCA } \\
+ \text { GEM }\end{array}$ & 1 & PD & 0.9 & 13.1 \\
\hline 2 & 46 & $F$ & Never & $\mathrm{Ad}$ & NA & 11.8 & $\mathrm{G} \rightarrow \mathrm{G}$ & 4.5 & DOC & 1 & PR & 6.4 & 24.6 \\
\hline 3 & 58 & $\mathrm{~F}$ & Ex & $\mathrm{Ad}$ & $\begin{array}{l}19 \\
\text { deletion }\end{array}$ & 38.4 & $\mathrm{G} \rightarrow \mathrm{G}$ & 2.8 & DOC & 1 & SD & 7.3 & 24.1 \\
\hline 4 & 70 & $\mathrm{~F}$ & Never & $\mathrm{Sq}$ & NA & 10.2 & $\mathrm{G} \rightarrow \mathrm{E}$ & 12.8 & GEM & 1 & SD & 1.7 & 4.3 \\
\hline 5 & 60 & $\mathrm{~F}$ & Never & $\mathrm{Ad}$ & NA & 13 & $\mathrm{G} \rightarrow \mathrm{G}$ & 5.4 & GEM & 1 & PD & 1.6 & 2.1 \\
\hline 6 & 63 & F & Never & $\mathrm{Ad}$ & NA & 7.4 & $\mathrm{G} \rightarrow \mathrm{E}$ & 2.6 & - & 3 & SD & 3.6 & 7.8 \\
\hline 7 & 52 & M & Never & $\mathrm{Ad}$ & L858R & 5.8 & $\mathrm{G} \rightarrow \mathrm{E}$ & 1 & - & 4 & SD & 6.4 & 6.4 \\
\hline 8 & 51 & M & Current & $\mathrm{Ad}$ & NA & 4.3 & $\mathrm{G} \rightarrow \mathrm{E}$ & 1.6 & AMR & 3 & PD & 0.6 & 0.9 \\
\hline 9 & 61 & $F$ & Never & $\mathrm{Ad}$ & NA & 8.5 & $\mathrm{G} \rightarrow \mathrm{E}$ & 2.3 & VNR & 3 & SD & 2.9 & 4 \\
\hline 10 & 53 & F & Never & $\mathrm{Ad}$ & NA & 12.9 & $\mathrm{G} \rightarrow \mathrm{E}$ & 0 & - & 4 & SD & 6.2 & 7.3 \\
\hline 11 & 54 & M & Current & $\mathrm{Ad}$ & $\begin{array}{l}19 \\
\text { deletion }\end{array}$ & 3.8 & $\mathrm{G} \rightarrow \mathrm{E}$ & 7.3 & VNR & 1 & SD & 3.2 & 5 \\
\hline
\end{tabular}

PFS, progression-free survival; TKI, tyrosine kinase inhibitor; PS, performance status; OS, overall survival; $F$, female; $M$, male; Ex, ex-smoker; Ad, adenocarcinoma; $\mathrm{Sq}$, squamous cell carcinoma; G, gefitinib; E, erlotinib; CBDCA, carboplatin; GEM, gemcitabine; DOC, docetaxel; AMR, amrubicin; VNR, vinorelbine; PR, partial response; $S D$, stable disease; $P D$, progressive disease.

$2^{\text {nd }}$ EGFR-TKI treatments. The median interval from the discontinuation of gefitinib to the $2^{\text {nd }}$ EGFR-TKI was 2.8 months (95\% CI, 1.9 - 6.9, Table 3). Only one patient (9\%) demonstrated PR, 7 (64\%) remained SD, and 3 (27\%) had PD. The DCR was 73\% (95\% CI, 43\% 91\%) and the median PFS was 3.4 months (95\% CI, 2 5.2). The median OS from the beginning of the $2^{\text {nd }}$ EGFR-TKI and from diagnosis were 7.3 months (95\% CI, 2.7 - 13.0) and 36.7 months (95\% CI, 23.6 - 43.9), respectively. No statistical differences in PFS or OS were observed between gefitinib and erlotinib as the $2^{\text {nd }}$ EGFR-TKI (PFS, $\mathrm{P}=0.23$ and OS, $\mathrm{P}=0.052$ ).

In contrast with previous studies, we further compared the clinical courses of the patients with those of gefitinib responders who were not treated with a $2^{\text {nd }}$ EGFR-TKI following gefitinib failure. We reviewed the

Table 3 Summary of prior therapy

\begin{tabular}{lrr}
\hline Characteristics & No. of patients & $\%$ \\
\hline No. of chemotherapy regimens before gefitinib & & \\
1 & 2 & 18 \\
2 & 4 & 36 \\
3 & 4 & 36 \\
4 & 1 & 9 \\
Best response to gefitinib & & \\
PR & 8 & 73 \\
SD & 3 & 27 \\
PFS to gefitinib & & \\
Median & 9.8 & \\
$95 \%$ Cl & $6.6-16.7$ & \\
Interval from discontinuation of gefitinib to 2 & \\
$\quad$ Median & & \\
$95 \%$ EGFR-TKI & 2.8 & \\
\hline
\end{tabular}

medical records at our institute and found 9 patients with backgrounds that were similar to those of the $2^{\text {nd }}$ EGFR-TKI patients (sex, age $(<70$ years old or $>70$ years old), histology, and response to gefitinib treatment). No statistical differences in PFS to $1^{\text {st }}$ gefitinib treatment were noted between both groups (9.8 months in the $2^{\text {nd }}$ TKI group and 8.7 months $(95 \% \mathrm{CI}$, 7.6 - 9.8) in the control group, $\mathrm{P}=0.87$ ). All of the identified control patients had been treated with platinum-doublet chemotherapy before gefitinib but had not received $2^{\text {nd }}$ EGFR-TKI. The OS from the start of the initial gefitinib treatment tended to be longer in patients who received a $2^{\text {nd }}$ EGFR-TKI (median OS, 21.5 months (95\% CI, 14.6 - 28.4)) compared to those in the control group (median OS, 12.3 months (95\% CI, 9.4 - 15.2), $\mathrm{P}=0.07$ ).

In the control group, 5 out of 9 patients had been treated with cytotoxic chemotherapy after gefitinib failure. To compare the efficacy of the $2^{\text {nd }}$ EGFR-TKI with chemotherapy after disease progression with gefitinib, data were collected from these 5 patients in the control group who had received chemotherapy after gefitinib failure (Table 4). The DCR for chemotherapy after gefitinib treatment was $20 \%$ and comprised one SD and four PD. The median PFS and OS from the start of chemotherapy after gefitinib treatment were only 2 months (95\% CI, $1.5-2.4$ ) and 2.5 months ( $95 \%$ CI, $2.2-2.8$ ), respectively. No significant differences in the PFS or OS from the start of treatment after gefitinib were observed between the patients who received a $2^{\text {nd }}$ EGFR-TKI and those who underwent cytotoxic chemotherapy (PFS, $\mathrm{P}=0.1$ and OS, $\mathrm{P}=$ 0.12 ); however, a $2^{\text {nd }}$ EGFR-TKI appeared to be a better option for gefitinib responders. 
Table 4 Tumor response to 2nd EGFR-TKI vs. chemotherapy

\begin{tabular}{|c|c|c|c|}
\hline Characteristics & $2^{\text {nd }} \mathrm{TKI}$ group & Control group & $\mathbf{P}$ \\
\hline \multicolumn{4}{|c|}{ OS from $1^{\text {st }}$ gefitinib } \\
\hline Median & 21.5 & 12.3 & 0.07 \\
\hline $95 \% \mathrm{Cl}$ & $14.6-28.4$ & $9.4-15.2$ & \\
\hline \multicolumn{4}{|c|}{ Response to $2^{\text {nd }}$ TKI or chemotherapy } \\
\hline $\mathrm{PR}$ & 1 & 0 & \\
\hline SD & 7 & 1 & \\
\hline PD & 3 & 4 & \\
\hline \multicolumn{4}{|c|}{ PFS to $2^{\text {nd }}$ TKI or chemotherapy } \\
\hline Median & 3.4 & 2 & 0.1 \\
\hline $95 \% \mathrm{Cl}$ & $2-5.2$ & $1.5-2.4$ & \\
\hline \multicolumn{4}{|c|}{ OS from $2^{\text {nd }} \mathrm{TKI}$ or chemotherapy } \\
\hline Median & 7.3 & 2.2 & 0.12 \\
\hline $95 \% \mathrm{Cl}$ & $2.7-13$ & $2.2-2.8$ & \\
\hline
\end{tabular}

Toxicity profiles for the initial gefitinib and $2^{\text {nd }}$ EGFR-TKI treatments

To determine whether the initial gefitinib treatment and EGFR-TKI retreatment caused similar adverse events, we assessed the toxicity profiles of all 11 patients (Table $5)$. The most common toxicity associated with both treatments was a grade $1 / 2$ skin rash. Although one patient presented a grade 3 elevation of $\gamma$-glutamyltranspeptidase during both treatment with gefitinib and with erlotinib (patient no. 7), the other observed toxicities were generally acceptable. In 5 patients, the toxicity profiles for the initial gefitinib and the $2^{\text {nd }}$ EGFR-TKI treatments were similar. None of the patients demonstrated interstitial lung disease in response to EGFR-TKI.

\section{Discussion}

To the best of our knowledge, 18 cases of patients who received gefitinib re-administration after failure of the initial gefitinib treatment have been reported to date, including 3 cases reported by our group (Table 6) [17-21]. All 18 patients responded to the initial gefitinib treatment, and most of the cases underwent cytotoxic chemotherapy between the first and second gefitinib therapy. Fourteen patients benefited from the $2^{\text {nd }}$ gefitinib treatment, and the overall DCR was $78 \%$. In our 3 patients, the toxicity of the $2^{\text {nd }}$ gefitinib was similar to that observed for the initial gefitinib treatment and was acceptable. Gefitinib retreatment is likely a good option for patients who have demonstrated a response to a previous gefitinib treatment.

Clinical studies have demonstrated that erlotinib is effective even in patients who are not considered to be good responders to gefitinib, such as those with a negative EGFR mutation, squamous cell carcinoma, or a history of smoking [22]. Because erlotinib is used at its maximum tolerated dose, whereas gefitinib is used at
Table 5 Toxicity profiles for the initial gefitinib and 2nd EGFR-TKI treatments. Adverse events were evaluated according to Common Terminology Criteria for Adverse Events of the National Cancer Institute (version 3.0).

\begin{tabular}{cll}
\hline Case & Initial gefitinib & 2 $^{\text {nd }}$ EGFR-TKI \\
\hline 1 & - & Rash G2 \\
2 & Rash G2 & - \\
3 & - & - \\
4 & Rash G2, Liver G1, Diarrhea G2 & Rash G1, Diarrhea G1 \\
5 & Rash G1 & Rash G2 \\
6 & Diarrhea G2, Taste alteration G2 & Rash G1, Diarrhea G1 \\
7 & Rash G2, Liver G3 & Rash G2, Liver G3 \\
8 & Rash G2 & Liver G2 \\
9 & Rash G1, Nail G1, Nausea G1 & Rash G1 \\
10 & Liver G1 & - \\
11 & - & Rash G1, Diarrhea G1 \\
\hline
\end{tabular}

G, grade; Liver, serum glutamic pyruvic transminase, serum glutamic oxaloacetic transaminase and $\gamma$-glutamyltranspeptidase.

only about one-third of its maximum tolerated dose in daily practice, the biological activity of erlotinib at standard doses may be higher than that of gefitinib [2,4,23-25]. These reports suggest that erlotinib may be active even in patients who demonstrated tumor progression during a prior gefitinib treatment. Thus, erlotinib has been selected as a treatment option for use after gefitinib failure (Table 7) [11-14,26-33]. In most studies, including the present investigation, favorable results have been documented, and the authors have concluded that erlotinib appears to be a useful treatment after gefitinib failure.

Although it is difficult to address the precise mechanism underlying these results, several studies have suggested a possible explanation for the clinical benefit of EGFR-TKI retreatment. Some cytotoxic agents have been reported to restore the sensitivity of NSCLC cells to gefitinib in vitro by increasing EGFR phosphorylation $[34,35]$. It is also possible that chemotherapy during the EGFR-TKI-free interval could decrease EGFR-TKI resistant tumor cells. However, no significant differences in PFS or OS were observed between our patients who received chemotherapy before the $2^{\text {nd }}$ EGFR-TKI and those who received the $2^{\text {nd }}$ EGFR-TKI immediately after gefitinib failure. In addition, the duration between the initial gefitinib and the $2^{\text {nd }}$ EGFR-TKI treatments was not associated with the response to $2^{\text {nd }}$ EGFR-TKI. Similarly to these findings, other researchers have found no evidence that either chemotherapy among the $1^{\text {st }}$ and $2^{\text {nd }}$ EGFR-TKIs or the duration of the EGFR-TKIfree period affects either PFS or OS in the $2^{\text {nd }}$ EGFRTKI [31,33].

Secondary EGFR mutations might be associated with the efficacy of erlotinib after gefitinib failure. MET amplification and secondary EGFR mutations, such as 
Table 6 Patient characteristics of the previous studies of gefitinib readministration

\begin{tabular}{|c|c|c|c|c|c|}
\hline \multirow[b]{2}{*}{ Author } & \multirow[b]{2}{*}{$\begin{array}{c}\text { No. of } \\
\text { patients }\end{array}$} & \multicolumn{2}{|c|}{ Response to gefitinib } & \multicolumn{2}{|c|}{$\begin{array}{l}\text { Response to } \\
2^{\text {nd }} \text { gefitinib }\end{array}$} \\
\hline & & CR/PR/SD & PD & CR/PR/SD & PD \\
\hline Yokouchi H et al. & 9 & 9 & - & 8 & 1 \\
\hline Yoshimoto A et al. & 1 & 1 & - & 1 & 0 \\
\hline Yano $S$ et al. & 3 & 3 & - & 2 & 1 \\
\hline Hashimoto $\mathrm{N}$ et al. & 1 & 1 & - & 0 & 1 \\
\hline Kurata T et al. & 1 & 1 & - & 1 & 0 \\
\hline
\end{tabular}

$\mathrm{CR}$, complete response.

T790 M, L747 S, D761Y, and T854A have been identified in NSCLC patients with an acquired resistance to EGFR-TKI [36-42]. T790 M mutation was found in $50 \%$, MET amplification in $20 \%$, and other secondary mutations in less than $5 \%$ of the NSCLC patients carrying EGFR mutations with TKI resistance $[43,44]$. In vitro studies have revealed that tumor cells carrying non-T790 M mutations show a partial resistance to EGFR-TKI, but are much less resistant compared to cells with T790 M. These data suggest that an increased EGFR-TKI dose might circumvent the acquired resistance caused by non-T790 M mutations. Previous studies have indicated that the serum concentration of erlotinib is several-fold higher than that of gefitinib at standard doses $[24,25]$. This difference in biological activities between the TKIs may contribute to the efficacy of erlotinib after gefitinib failure in patients carrying non-T790 M mutations.

In conclusion, our findings suggest that a $2^{\text {nd }}$ EGFRTKI can be a treatment option for patients who benefited from a previous gefitinib treatment. However, as shown

Table 7 Patient characteristics of the previous studies of erlotinib after gefitinib failure

\begin{tabular}{|c|c|c|c|c|c|c|}
\hline \multirow[b]{2}{*}{ Author } & \multirow[b]{2}{*}{$\begin{array}{r}\text { No. of } \\
\text { patients }\end{array}$} & \multicolumn{2}{|c|}{$\begin{array}{l}\text { Response to } \\
\text { gefitinib }\end{array}$} & \multicolumn{3}{|c|}{$\begin{array}{l}\text { Response to } \\
\text { erlotinib }\end{array}$} \\
\hline & & $\begin{array}{r}\text { CR/PR/ } \\
\mathrm{SD}\end{array}$ & PD & $\begin{array}{r}\text { CR/PR/ } \\
\text { SD }\end{array}$ & PD & $\begin{array}{r}\text { DCR } \\
(\%)\end{array}$ \\
\hline Lee DH et al. & 23 & 17 & 6 & 2 & 21 & 9 \\
\hline Cho BC et al. & 21 & 10 & 11 & 6 & 15 & 29 \\
\hline $\begin{array}{l}\text { Viswanathan A } \\
\text { et al. }\end{array}$ & 5 & 4 & 1 & 0 & 5 & 0 \\
\hline Costa DB et al. & 18 & 16 & 2 & 4 & 14 & 22 \\
\hline Sim SH et al. & 16 & 11 & 5 & 4 & 12 & 25 \\
\hline Chang JW et al. & 1 & 1 & 0 & 1 & 0 & 100 \\
\hline Garfield DH et al. & 1 & 1 & 0 & 1 & 0 & 100 \\
\hline Vasile E et al. & 8 & 8 & 0 & 5 & 3 & 63 \\
\hline Gridelli C et al. & 3 & 3 & 0 & 3 & 0 & 100 \\
\hline Wong AS et al. & 14 & 9 & 5 & 5 & 9 & 36 \\
\hline Zhou ZT et al. & 21 & 15 & 6 & 10 & 11 & 48 \\
\hline Wong MK et al. & 21 & 18 & 3 & 12 & 9 & 57 \\
\hline
\end{tabular}

in Table 7 some studies failed to demonstrate the efficacy of $2^{\text {nd }}$ EGFR-TKI after gefitinib failure. Cho et al. mentioned that the tumor response to $1^{\text {st }}$ gefitinib treatment can be a predictive marker [14]. They described that patients who showed SD during $1^{\text {st }}$ gefitinib treatment had better survival with $2^{\text {nd }}$ EGFR-TKI, however those who had PD to $1^{\text {st }}$ gefitinib rarely responded to $2^{\text {nd }}$ EGFR-TKI. The difference in the percentage of patients with a good predictor might affect the results of these trials about $2^{\text {nd }}$ EGFR-TKI. Intense research has been devoted to clarifying the mechanism responsible for acquired resistance, but it is difficult to obtain clinical samples from all patients to confirm MET amplification or secondary mutations. Jackman et al. recently published a clinical definition of acquired resistance to EGFR-TKI [45]. This consensus definition will facilitate the establishment of standard entry criteria for studies investigating acquired resistance. All of our patients except one met these criteria (no. 8 in Table 2). Despite rapid tumor progression during a previous cytotoxic chemotherapy, this patient obtained SD with an initial gefitinib therapy of 4.3 months, and therefore we considered this patient to have benefited from the gefitinib treatment. Further clinical trials are required to develop a novel treatment for patients with acquired resistance.

\section{Conclusion}

In the current study, we analyzed the efficacy and toxicity of a $2^{\text {nd }}$ EGFR-TKI treatment in patients who demonstrated a response to prior gefitinib therapy and tumor progression. A second EGFR-TKI treatment was generally effective in patients who had benefited from the initial gefitinib therapy. The adverse events associated with a $2^{\text {nd }}$ EGFR-TKI were acceptable and comparable with those observed for the initial gefitinib therapy. In Japan, gefitinib has been approved for the treatment of inoperable and recurrent NSCLC since 2002, and many patients have already experienced a need for a new treatment option following gefitinib treatment. Based on the present data, a $2^{\text {nd }}$ EGFR-TKI treatment could represent a potentially new treatment for gefitinib responders. Prospective clinical trials and translational analyses in this area of research are warranted.

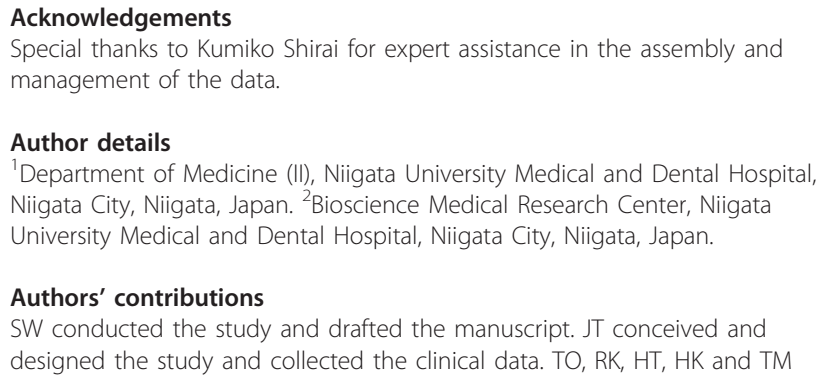


participated in the patient care, and collected the data. KI, JK and JB analyzed and interpreted the data. IN and HY provided the administrative support. All the authors have read and approved the final version of the manuscript.

\section{Competing interests}

The authors declare that they have no competing interests.

Received: 1 February 2010 Accepted: 1 January 2011

Published: 1 January 2011

\section{References}

1. Fukuoka M, Yano S, Giaccone G, Tamura T, Nakagawa K, Douillard JY, Nishiwaki Y, Vansteenkiste J, Kudoh S, Rischin D, Eek R, Horai T, Noda K, Takata I, Smit E, Averbuch S, Macleod A, Feyereislova A, Dong RP, Baselga J: Multi-institutional randomized phase II trial of gefitinib for previously treated patients with advanced non-small-cell lung cancer (The IDEAL 1 Trial) [corrected]. J Clin Oncol 2003, 21:2237-2246.

2. Kris MG, Natale RB, Herbst RS, Lynch TJ, Prager D, Belani CP, Schiller JH, Kelly K, Spiridonidis H, Sandler A, Albain KS, Cella D, Wolf MK, Averbuch SD, Ochs JJ, Kay AC: Efficacy of gefitinib, an inhibitor of the epidermal growth factor receptor tyrosine kinase, in symptomatic patients with non-small cell lung cancer: a randomized trial. JAMA 2003, 290:2149-2158.

3. Kim ES, Hirsh V, Mok T, Socinski MA, Gervais R, Wu YL, Li LY, Watkins CL, Sellers MV, Lowe ES, Sun Y, Liao ML, Osterlind K, Reck M, Armour AA, Shepherd FA, Lippman SM, Douillard JY: Gefitinib versus docetaxel in previously treated non-small-cell lung cancer (INTEREST): a randomised phase III trial. Lancet 2008, 372:1809-1818.

4. Thatcher N, Chang A, Parikh P, Rodrigues Pereira J, Ciuleanu T, von Pawel J, Thongprasert S, Tan EH, Pemberton K, Archer V, Carroll K: Gefitinib plus best supportive care in previously treated patients with refractory advanced non-small-cell lung cancer: results from a randomised, placebo-controlled, multicentre study (Iressa Survival Evaluation in Lung Cancer). Lancet 2005, 366:1527-1537.

5. Chang GC, Tsai CM, Chen KC, Yu CJ, Shih JY, Yang TY, Lin CP, Hsu JY, Chiu CH, Perng RP, Yang PC, Yang CH: Predictive factors of gefitinib antitumor activity in East Asian advanced non-small cell lung cancer patients. J Thorac Oncol 2006, 1:520-525.

6. Lynch TJ, Bell DW, Sordella R, Gurubhagavatula S, Okimoto RA, Brannigan BW, Harris PL, Haserlat SM, Supko JG, Haluska FG, Louis DN Christiani DC, Settleman J, Haber DA: Activating mutations in the epidermal growth factor receptor underlying responsiveness of nonsmall-cell lung cancer to gefitinib. N Engl J Med 2004, 350:2129-2139.

7. Paez JG, Janne PA, Lee JC, Tracy S, Greulich H, Gabriel S, Herman P, Kaye FJ, Lindeman N, Boggon TJ, Naoki K, Sasaki H, Fujii Y, Eck MJ, Sellers WR, Johnson BE, Meyerson M: EGFR mutations in lung cancer: correlation with clinical response to gefitinib therapy. Science 2004, 304:1497-1500.

8. Mitsudomi T, Kosaka $T$, Endoh $H$, Horio $Y$, Hida T, Mori S, Hatooka S, Shinoda M, Takahashi T, Yatabe Y: Mutations of the epidermal growth factor receptor gene predict prolonged survival after gefitinib treatment in patients with non-small-cell lung cancer with postoperative recurrence. J Clin Oncol 2005, 23:2513-2520.

9. Mok TS, Wu YL, Thongprasert S, Yang CH, Chu DT, Saijo N, Sunpaweravong $P$, Han B, Margono B, Ichinose $Y$, Nishiwaki $Y$, Ohe $Y$, Yang JJ, Chewaskulyong B, Jiang H, Duffield EL, Watkins CL, Armour AA, Fukuoka M: Gefitinib or carboplatin-paclitaxel in pulmonary adenocarcinoma. N Engl J Med 2009, 361:947-957.

10. Maemondo M, Inoue A, Kobayashi K, Sugawara S, Oizumi S, Isobe H, Gemma A, Harada M, Yoshizawa H, Kinoshita I, Fujita Y, Okinaga S, Hirano H, Yoshimori K, Harada T, Ogura T, Ando M, Miyazawa H, Tanaka T, Saijo Y, Hagiwara K, Morita S, Nukiwa T: Gefitinib or chemotherapy for non-small-cell lung cancer with mutated EGFR. N Engl J Med 362:2380-2388.

11. Chang JW, Chou CL, Huang SF, Wang HM, Hsieh JJ, Hsu T, Cheung YC: Erlotinib response of EGFR-mutant gefitinib-resistant non-small-cell lung cancer. Lung Cancer 2007, 58:414-417.

12. Gridelli C, Maione P, Galetta D, Colantuoni G, Del Gaizo F, Ferrara C, Guerriero C, Nicolella D, Rossi A: Three cases of long-lasting tumor control with erlotinib after progression with gefitinib in advanced non-small cell lung cancer. J Thorac Oncol 2007, 2:758-761.
13. Costa DB, Nguyen KS, Cho BC, Sequist LV, Jackman DM, Riely GJ, Yeap BY, Halmos B, Kim JH, Janne PA, Huberman MS, Pao W, Tenen DG, Kobayashi S: Effects of erlotinib in EGFR mutated non-small cell lung cancers with resistance to gefitinib. Clin Cancer Res 2008, 14:7060-7067.

14. Cho BC, Im CK, Park MS, Kim SK, Chang J, Park JP, Choi HJ, Kim YJ, Shin SJ, Sohn JH, Kim H, Kim JH: Phase II study of erlotinib in advanced nonsmall-cell lung cancer after failure of gefitinib. J Clin Oncol 2007, 25:2528-2533.

15. Therasse P, Arbuck SG, Eisenhauer EA, Wanders J, Kaplan RS, Rubinstein L, Verweij J, Van Glabbeke M, van Oosterom AT, Christian MC, Gwyther SG: New guidelines to evaluate the response to treatment in solid tumors. European Organization for Research and Treatment of Cancer, National Cancer Institute of the United States, National Cancer Institute of Canada. J Natl Cancer Inst 2000, 92:205-216.

16. Trotti A, Colevas AD, Setser A, Rusch V, Jaques D, Budach V, Langer $C$, Murphy B, Cumberlin R, Coleman CN, Rubin P: CTCAE v3.0: development of a comprehensive grading system for the adverse effects of cancer treatment. Semin Radiat Oncol 2003, 13:176-181.

17. Yokouchi H, Yamazaki K, Kinoshita I, Konishi J, Asahina H, Sukoh N, Harada M, Akie K, Ogura S, Ishida T, Munakata M, Dosaka-Akita H, Isobe H, Nishimura M: Clinical benefit of readministration of gefitinib for initial gefitinib-responders with non-small cell lung cancer. BMC Cancer 2007, 7.51.

18. Yoshimoto A, Inuzuka K, Kita T, Kawashima A, Kasahara K: Remarkable effect of gefitinib retreatment in a patient with nonsmall cell lung cancer who had a complete response to initial gefitinib. Am J Med Sci 2007, 333:221-225.

19. Yano S, Nakataki E, Ohtsuka S, Inayama M, Tomimoto H, Edakuni N, Kakiuchi S, Nishikubo N, Muguruma H, Sone S: Retreatment of lung adenocarcinoma patients with gefitinib who had experienced favorable results from their initial treatment with this selective epidermal growth factor receptor inhibitor: a report of three cases. Oncol Res 2005, 15:107-111.

20. Hashimoto N, Imaizumi K, Honda T, Kawabe T, Nagasaka T, Shimokata K, Hasegawa Y: Successful re-treatment with gefitinib for carcinomatous meningitis as disease recurrence of non-small-cell lung cancer. Lung Cancer 2006, 53:387-390.

21. Kurata T, Tamura K, Kaneda H, Nogami T, Uejima H, Asai Go G, Nakagawa K, Fukuoka M: Effect of re-treatment with gefitinib ('Iressa', ZD1839) after acquisition of resistance. Ann Oncol 2004, 15:173-174.

22. Shepherd FA, Rodrigues Pereira J, Ciuleanu T, Tan EH, Hirsh V, Thongprasert S, Campos D, Maoleekoonpiroj S, Smylie M, Martins R, van Kooten M, Dediu M, Findlay B, Tu D, Johnston D, Bezjak A, Clark G, Santabarbara $P$, Seymour L: Erlotinib in previously treated non-small-cell lung cancer. N Engl J Med 2005, 353:123-132.

23. Baselga J, Arteaga CL: Critical update and emerging trends in epidermal growth factor receptor targeting in cancer. J Clin Oncol 2005, 23:2445-2459

24. Baselga J, Rischin D, Ranson M, Calvert H, Raymond E, Kieback DG, Kaye SB, Gianni L, Harris A, Bjork T, Averbuch SD, Feyereislova A, Swaisland H, Rojo F, Albanell J: Phase I safety, pharmacokinetic, and pharmacodynamic trial of ZD1839, a selective oral epidermal growth factor receptor tyrosine kinase inhibitor, in patients with five selected solid tumor types. J Clin Oncol 2002, 20:4292-4302.

25. Hidalgo M, Siu LL, Nemunaitis J, Rizzo J, Hammond LA, Takimoto C, Eckhardt SG, Tolcher A, Britten CD, Denis L, Ferrante K, Von Hoff DD, Silberman S, Rowinsky EK: Phase I and pharmacologic study of OSI-774, an epidermal growth factor receptor tyrosine kinase inhibitor, in patients with advanced solid malignancies. J Clin Oncol 2001, 19:3267-3279.

26. Lee DH, Kim SW, Suh C, Yoon DH, Yi EJ, Lee JS: Phase II study of erlotinib as a salvage treatment for non-small-cell lung cancer patients after failure of gefitinib treatment. Ann Oncol 2008, 19:2039-2042.

27. Viswanathan A, Pillot G, Govindan R: Lack of response to erlotinib after progression on gefitinib in patients with advanced non-small cell lung cancer. Lung Cancer 2005, 50:417-418.

28. Sim SH, Han SW, Oh DY, Lee SH, Kim DW, Im SA, Chung DH, Kim TY, Lee JS, Kim YW, Heo DS, Bang YJ: Erlotinib after Gefitinib failure in female never-smoker Asian patients with pulmonary adenocarcinoma. Lung Cancer 2009, 65:204-207. 
29. Garfield DH: Modern treatment of lung cancer: case 2. Response to erlotinib after failure of gefitinib in a patient with advanced non-smallcell lung carcinoma. J Clin Oncol 2005, 23:7738-7740.

30. Vasile E, Tibaldi C, Chella A, Falcone A: Erlotinib after failure of gefitinib in patients with advanced non-small cell lung cancer previously responding to gefitinib. J Thorac Oncol 2008, 3:912-914.

31. Wong AS, Soong R, Seah SB, Lim SW, Chuah KL, Nga ME, Chin TM, Soo RA: Evidence for disease control with erlotinib after gefitinib failure in typical gefitinib-sensitive Asian patients with non-small cell lung cancer. J Thorac Oncol 2008, 3:400-404.

32. Zhou ZT, Xu XH, Wei Q, Lu MQ, Wang J, Wen CH: Erlotinib in advanced non-small-cell lung cancer after gefitinib failure. Cancer Chemother Pharmacol 2009, 64:1123-1127.

33. Wong MK, Lo Al, Lam B, Lam WK, Ip MS, Ho JC: Erlotinib as salvage treatment after failure to first-line gefitinib in non-small cell lung cancer. Cancer Chemother Pharmacol 2009, 65:1023-1028.

34. Van Schaeybroeck S, Karaiskou-McCaul A, Kelly D, Longley D, Galligan L, Van Cutsem E, Johnston P: Epidermal growth factor receptor activity determines response of colorectal cancer cells to gefitinib alone and in combination with chemotherapy. Clin Cancer Res 2005, 11:7480-7489.

35. Van Schaeybroeck S, Kyula J, Kelly DM, Karaiskou-McCaul A, Stokesberry SA, Van Cutsem E, Longley DB, Johnston PG: Chemotherapy-induced epidermal growth factor receptor activation determines response to combined gefitinib/chemotherapy treatment in non-small cell lung cancer cells. Mol Cancer Ther 2006, 5:1154-1165.

36. Engelman JA, Zejnullahu K, Mitsudomi T, Song Y, Hyland C, Park JO, Lindeman N, Gale CM, Zhao X, Christensen J, Kosaka T, Holmes AJ, Rogers AM, Cappuzzo F, Mok T, Lee C, Johnson BE, Cantley LC, Janne PA: MET amplification leads to gefitinib resistance in lung cancer by activating ERBB3 signaling. Science 2007, 316:1039-1043.

37. Bean J, Brennan C, Shih JY, Riely G, Viale A, Wang L, Chitale D, Motoi N, Szoke J, Broderick S, Balak M, Chang WC, Yu CJ, Gazdar A, Pass H, Rusch V, Gerald W, Huang SF, Yang PC, Miller V, Ladanyi M, Yang CH, Pao W: MET amplification occurs with or without T790 M mutations in EGFR mutant lung tumors with acquired resistance to gefitinib or erlotinib. Proc Natl Acad Sci USA 2007, 104:20932-20937.

38. Kobayashi S, Boggon TJ, Dayaram T, Janne PA, Kocher O, Meyerson M, Johnson BE, Eck MJ, Tenen DG, Halmos B: EGFR mutation and resistance of non-small-cell lung cancer to gefitinib. N Engl J Med 2005, 352:786-792.

39. Pao W, Miller VA, Politi KA, Riely GJ, Somwar R, Zakowski MF, Kris MG, Varmus $\mathrm{H}$ : Acquired resistance of lung adenocarcinomas to gefitinib or erlotinib is associated with a second mutation in the EGFR kinase domain. PLoS Med 2005, 2:e73.

40. Costa DB, Halmos B, Kumar A, Schumer ST, Huberman MS, Boggon TJ, Tenen DG, Kobayashi S: BIM mediates EGFR tyrosine kinase inhibitorinduced apoptosis in lung cancers with oncogenic EGFR mutations. PLOS Med 2007, 4:1669-1679, discussion 1680

41. Balak MN, Gong Y, Riely GJ, Somwar R, Li AR, Zakowski MF, Chiang A, Yang G, Ouerfelli O, Kris MG, Ladanyi M, Miller VA, Pao W: Novel D761Y and common secondary T790 M mutations in epidermal growth factor receptor-mutant lung adenocarcinomas with acquired resistance to kinase inhibitors. Clin Cancer Res 2006, 12:6494-6501.

42. Bean J, Riely GJ, Balak M, Marks JL, Ladanyi M, Miller VA, Pao W: Acquired resistance to epidermal growth factor receptor kinase inhibitors associated with a novel T854A mutation in a patient with EGFR-mutant lung adenocarcinoma. Clin Cancer Res 2008, 14:7519-7525.

43. Yamamoto $\mathrm{H}$, Toyooka S, Mitsudomi T: Impact of EGFR mutation analysis in non-small cell lung cancer. Lung Cancer 2009, 63:315-321.

44. Nguyen KS, Kobayashi S, Costa DB: Acquired resistance to epidermal growth factor receptor tyrosine kinase inhibitors in non-small-cell lung cancers dependent on the epidermal growth factor receptor pathway. Clin Lung Cancer 2009, 10:281-289.

45. Jackman D, Pao W, Riely GJ, Engelman JA, Kris MG, Janne PA, Lynch T, Johnson BE, Miller VA: Clinical definition of acquired resistance to epidermal growth factor receptor tyrosine kinase inhibitors in non-smallcell lung cancer. J Clin Oncol 28:357-360.

\section{Pre-publication history}

The pre-publication history for this paper can be accessed here:

http://www.biomedcentral.com/1471-2407/11/1/prepub doi:10.1186/1471-2407-11-1

Cite this article as: Watanabe et al:: Clinical responses to EGFR-tyrosine kinase inhibitor retreatment in non-small cell lung cancer patients who benefited from prior effective gefitinib therapy: a retrospective analysis. BMC Cancer 2011 11:1.

\section{Submit your next manuscript to BioMed Central and take full advantage of:}

- Convenient online submission

- Thorough peer review

- No space constraints or color figure charges

- Immediate publication on acceptance

- Inclusion in PubMed, CAS, Scopus and Google Scholar

- Research which is freely available for redistribution

Submit your manuscript at www.biomedcentral.com/submit
C Biomed Central 